\title{
Fractional deuteration applied to biomolecular solid-state NMR spectroscopy
}

\author{
Deepak Nand · Abhishek Cukkemane • \\ Stefan Becker • Marc Baldus
}

Received: 14 September 2011/ Accepted: 29 October 2011/Published online: 22 November 2011

(C) The Author(s) 2011. This article is published with open access at Springerlink.com

\begin{abstract}
Solid-state Nuclear Magnetic Resonance can provide detailed insight into structural and dynamical aspects of complex biomolecules. With increasing molecular size, advanced approaches for spectral simplification and the detection of medium to long-range contacts become of critical relevance. We have analyzed the protonation pattern of a membrane-embedded ion channel that was obtained from bacterial expression using protonated precursors and $\mathrm{D}_{2} \mathrm{O}$ medium. We find an overall reduction of $50 \%$ in protein protonation. High levels of deuteration at $\mathrm{H}_{\alpha}$ and $\mathrm{H}_{\beta}$ positions reduce spectral congestion in $\left({ }^{1} \mathrm{H},{ }^{13} \mathrm{C},{ }^{15} \mathrm{~N}\right)$ correlation experiments and generate a transfer profile in longitudinal mixing schemes that can be tuned to specific resonance frequencies. At the same time, residual protons are predominantly found at amino-acid side-chain positions enhancing the prospects for obtaining side-chain resonance assignments and for detecting medium to long-range contacts. Fractional deuteration thus provides a powerful means to aid the structural analysis of complex biomolecules by solid-state NMR.
\end{abstract}

Keywords Assignment - Deuteration · Ion channel · MAS · Solid-state NMR · Structural constraints

Electronic supplementary material The online version of this article (doi:10.1007/s10858-011-9585-2) contains supplementary material, which is available to authorized users.

D. Nand $\cdot$ A. Cukkemane $\cdot$ M. Baldus $(\bowtie)$

Bijvoet Center for Biomolecular Research, Utrecht University, Padualaan 8, 3584, CH, Utrecht, The Netherlands

e-mail: m.baldus@uu.nl

\section{S. Becker}

Department of NMR-based Structural Biology, Max-PlanckInstitute for Biophysical Chemistry, Am Fassberg 11, 37077 Göttingen, Germany

\section{Introduction}

Solid-state Nuclear Magnetic Resonance (ssNMR) combined with Magic Angle Spinning (MAS, (Andrew et al. 1958)) has in the last years made significant progress to study complex biomolecular systems including membrane proteins (Lange et al. 2006a; Ader et al. 2008; Bajaj et al. 2009; Ahuja et al. 2009; Shi et al. 2009; Etzkorn et al. 2007, 2010; Cady et al. 2010) or protein assemblies (Heise et al. 2005; Andronesi et al. 2008; Wasmer et al. 2008; Poyraz et al. 2010; Sun et al. 2009; Kumar et al. 2010; Jehle et al. 2010). In parallel, methods have been devised to determine entire three-dimensional structures from a single (Nomura et al. 1999; Rienstra et al. 2002; Lange et al. 2005; Manolikas et al. 2008; Bertini et al. 2010a) or a few (Castellani et al. 2002) protein preparations. With increasing molecular size, spectral resolution becomes critical for several aspects of the structure determination process. To deal with these challenges, multi-dimensional correlation experiments have been proposed and more elaborate isotope labeling schemes have been used (See Renault et al. 2010 for a recent overview). Some of the latter approaches simplify the spectral analysis to detect certain protein resonances but the essential process of structure determination, i.e., polarization transfer via $\mathrm{C}-\mathrm{C}$, C/N-HH-C (Lange et al. 2002)), or C/N-H-C (Seidel et al. 2005; Paepe et al. 2008; De Paepe et al. 2011)) spin moieties remains largely unaffected. At the same time, protein deuteration that has long been recognized as a powerful tool for macromolecular structural analysis by solutionstate NMR (Englander et al. 1996; Gardner and Kay 1998) has been introduced in ssNMR for resolution enhancement of ${ }^{1} \mathrm{H}$ solid-state NMR (Pines et al. 1976; McDermott et al. 1992; Zheng et al. 1993). In the last years, such approaches have been optimized to further reduce ${ }^{1} \mathrm{H}$ line width 
(Chevelkov et al. 2006; Zhou et al. 2007; Linser et al. 2011), establish structural constraints (Reif et al. 2001; Paulson et al. 2003; Reif et al. 2003; Zhou et al. 2007; Huber et al. 2011; Varga et al. 2007) and to characterize protein-water interactions (Bockmann et al. 2005; Lesage et al. 2006). However, increasing levels of deuteration compromise the prospects to probe structurally relevant proton-proton distance constraints, affect relaxation times and may be prohibited by reduced protein expression levels in complex biomolecules such as membrane proteins.

In the following, we show that fractional deuteration (Rosen et al. 1996; Shekhtman et al. 2002; Otten et al. 2010) which can be readily obtained during protein expression by the combined use of protonated precursors and $\mathrm{D}_{2} \mathrm{O}$ provides a route to reduce spectral crowding and enhances the prospects to detect long-range correlations in standard ssNMR correlation experiments on complex biomolecules. For our study, we produced a fractionally deuterated version of a chimeric potassium channel (KcsA-Kv1.3) for which ssNMR resonance assignments have been reported (Schneider et al. 2008) and which has previously been characterized by ssNMR in different functional states in a lipid bilayer environment (Ader et al. 2008; Ader et al. 2009a, b). We analyzed the residual level of protein protonation and the effect of fractional deuteration on $\left({ }^{13} \mathrm{C},{ }^{13} \mathrm{C}\right)$ as well as $\left({ }^{15} \mathrm{~N},{ }^{13} \mathrm{C}\right)$ and $\left({ }^{1} \mathrm{H},{ }^{13} \mathrm{C}\right)$ ssNMR experiments. We show that a substantial reduction in proton density in $\left[{ }^{1} \mathrm{H} /{ }^{2} \mathrm{H},{ }^{13} \mathrm{C},{ }^{15} \mathrm{~N}\right]$ labeled KcsA-Kv1.3 influences the polarization transfer dynamics in the context of chemical-shift selective transfer. Because the residual protonation level favours peripheral amino-acid positions, establishing side-chain resonance assignments as well as the detection of longrange contacts, in particular between aromatic and methyl side-chains, is facilitated.

\section{Materials and methods}

\section{Preparation of $\left[{ }^{1} \mathrm{H} /{ }^{2} \mathrm{H},{ }^{13} \mathrm{C},{ }^{15} \mathrm{~N}\right] \mathrm{KcsA}-\mathrm{Kv} 1.3$}

Following the work of Legros et al. (Legros et al. 2000), the pQE32 expression construct (Lange et al. 2006a) was transformed into E.coli strain M15 prep4. For protein production, E.coli cells were grown on a medium containing protonated glucose and $\mathrm{D}_{2} \mathrm{O}$. Cultures were adapted from initially 33-99\% $\mathrm{D}_{2} \mathrm{O}$ over 3 days on small scale shaker flasks containing M9 minimal medium. The final culture was tenfold diluted into the expression culture. Protein expression was induced at $25^{\circ} \mathrm{C}$ by adding $0.5 \mathrm{mM}$ IPTG at $\mathrm{OD}_{600}=0.9$. Cells were harvested as soon as the stationary phase was reached (5-6 h after induction). The protein was purified from $10 \mathrm{~L}$ of expression culture as described before (Lange et al. 2006a, b). Reconstitution into Asolectin liposomes was performed as described (Lange et al. 2006a, b), with minor changes. Briefly, the buffer of the purified channel protein was exchanged against $50 \mathrm{mM}$ Sodium Phosphate, $\mathrm{pH}$ 7.4, $100 \mathrm{mM}$ Sodium chloride, $4 \mathrm{mM}$ n-decyl-ß-Dmaltopyranoside (DM) (Calbiochem) using a HiPrep 26/10 desalting column (GE Healthcare). Asolectin from soybean (Fluka) was resuspended in the same buffer and added at a 100/1 Asolection/KcsA-Kv1.3 molar ratio. This suspension was incubated for $2 \mathrm{~h}$ at room temperature. Subsequently, detergent was removed with Calbiosorb Adsorbent (Calbiochem). Liposomes containing $\left[{ }^{1} \mathrm{H} /{ }^{2} \mathrm{H},{ }^{13} \mathrm{C},{ }^{15} \mathrm{~N}\right]$-labeled KcsA-Kv1.3 protein were pelleted by centrifugation at $134,000 \times \mathrm{g}$ for $2 \mathrm{~h}$ at $4^{\circ} \mathrm{C}$.

\section{Solid-state NMR}

All experiments were recorded using a $3.2 \mathrm{~mm}$ triple-resonance $\left({ }^{1} \mathrm{H},{ }^{13} \mathrm{C},{ }^{15} \mathrm{~N}\right)$ probe head at a static magnetic field of $16.4 \mathrm{~T}$ corresponding to $700 \mathrm{MHz}$ proton resonance frequency (Bruker Biospin, Karlsruhe, Germany). ${ }^{1} \mathrm{H}$ field strengths of $83.3 \mathrm{kHz}$ were employed for $90^{\circ}$ pulses and SPINAL64 (Ref. (Fung et al. 2000)) decoupling during evolution and detection periods. Initial $\left({ }^{1} \mathrm{H},{ }^{13} \mathrm{C}\right)$ crosspolarization $(\mathrm{CP})$ times were set to $80 \mu \mathrm{s}$ to largely restrict polarization transfer to directly bonded ${ }^{1} \mathrm{H}_{-}{ }^{13} \mathrm{C}$ spin pairs in $\left({ }^{1} \mathrm{H},{ }^{13} \mathrm{C}\right)$ and $\left({ }^{13} \mathrm{C},{ }^{13} \mathrm{C}\right)$ correlation experiments. For $\left({ }^{15} \mathrm{~N},{ }^{13} \mathrm{C}\right)$ correlation experiments, an initial $\left({ }^{1} \mathrm{H},{ }^{15} \mathrm{~N}\right) \mathrm{CP}$ time of $800 \mu$ s was used. ${ }^{15} \mathrm{~N}-{ }^{13} \mathrm{C}$ transfers were performed with a SPECIFIC-CP (Baldus et al. 1998) time of $3 \mathrm{~ms}$, followed by homonuclear ${ }^{13} \mathrm{C}-{ }^{13} \mathrm{C}$ DARR (Takegoshi et al. 2001) mixing of $100 \mathrm{~ms}$ under $10.92 \mathrm{kHz}$ MAS. $\left({ }^{1} \mathrm{H},{ }^{13} \mathrm{C}\right)$ correlation experiments were conducted using frequencyswitched homonuclear Lee-Goldburg (FSLG, Bielecki et al. 1989) decoupling at $83.3 \mathrm{kHz}{ }^{1} \mathrm{H}$ field strength during the indirect ${ }^{1} \mathrm{H}$ evolution period and the proton dimension was calibrated using regular $\left({ }^{1} \mathrm{H},{ }^{13} \mathrm{C}\right)$ HETCOR spectra. For ${ }^{1} \mathrm{H}-{ }^{1} \mathrm{H}$ double-quantum (DQ) mixing, we employed the SPC5 recoupling scheme (Hohwy et al. 2002) with DQ excitation and reconversion times of $285 \mu$ s and a CP time as in the FSLG HETCOR experiments. To enhance rotational resonance recoupling for carboxyls and backbone $\mathrm{C} \alpha$ 's, MAS rates were set to $10.92 \mathrm{kHz}$ or $8.5 \mathrm{kHz}$. Transfer among aromatic and aliphatic methyl side chains was enhanced using an MAS rate of $10 \mathrm{kHz}$. Mixing times ranged from 20 to $500 \mathrm{~ms}$ in $\left({ }^{13} \mathrm{C},{ }^{13} \mathrm{C}\right)$ proton-driven spindiffusion (PDSD) experiments. All experiments were performed with an effective sample temperatures ranging from $+2^{\circ} \mathrm{C}$ to $+7^{\circ} \mathrm{C}$. Spectra were processed in Topspin (Bruker Biospin) and analyzed with Sparky (T. D. Goddard and D. G. Kneller, SPARKY 3, University of California, San Francisco). 
Assignment and structural analysis

SsNMR resonance assignments for KcsA-Kv1.3 in lipid bilayers were taken from Ref. (Schneider et al. 2008). Since KcsA-Kv1.3 only differs by 11 turret residues from the $4 \times 160$ amino acid KcsA channel (Schneider et al. 2008) and in line with previous ssNMR work (Ader et al. 2008; Schneider et al. 2008; Ader et al. 2009b), the structure of the closed-conductive state of KcsA-Kv1.3 must share essential structural features with crystalline KcsA. Therefore, we created a structural homologue of the KcsA-Kv1.3 channel in the closed conductive state using the crystal structure of full length KcsA (PDB ID 3EFF, Uysal et al. 2009). Intra- and intermolecular ${ }^{13} \mathrm{C}-{ }^{13} \mathrm{C}$ correlations were then predicted using the KcsA-Kv1.3 model with an upper distance cutoff of $5 \AA$ \& $6 \AA$ and, at the same time, taking into account the residual protonation pattern identified from ssNMR experiments. With these cutoff parameters (which were varied between 4 and $8 \AA$ ) we observed the best overall agreement between experimental data sets and predicted cross peak patterns.

\section{Results}

Identification of residual protonation pattern

To investigate the residual level of protonation of $\left[{ }^{1} \mathrm{H} /{ }^{2} \mathrm{H},{ }^{13} \mathrm{C},{ }^{15} \mathrm{~N}\right] \mathrm{Kcs} \mathrm{A}-\mathrm{Kv} 1.3$ in lipid bilayers, we compared a series of two-dimensional ssNMR experiments with previous solution-state NMR work (Rosen et al. 1996; Shekhtman et al. 2002; Otten et al. 2010) and amino-acid biosynthetic pathways (Nelson and Cox 2008). Firstly, we conducted a conventional $\left({ }^{13} \mathrm{C},{ }^{13} \mathrm{C}\right)$ proton-driven spin diffusion experiment using a mixing time of $20 \mathrm{~ms}$ using short (Fig. 1a) and longer CP (Fig. 1b, black) times.

The aliphatic region of the resulting spectrum is largely devoid of $\mathrm{C} \alpha-\mathrm{C} \beta$ correlations (such as relating to Ile, Lys, Phe, Tyr or Asp residues), except for amino acids in which only one of the ${ }^{13} \mathrm{C}$ positions is deuterated (Fig. 1a, red). For such protein residues (Ser, Thr, Cys, etc.) we observe, as expected for the short $\mathrm{CP}$ time (used in Fig. 1a), asymmetric correlation peaks. In line with earlier

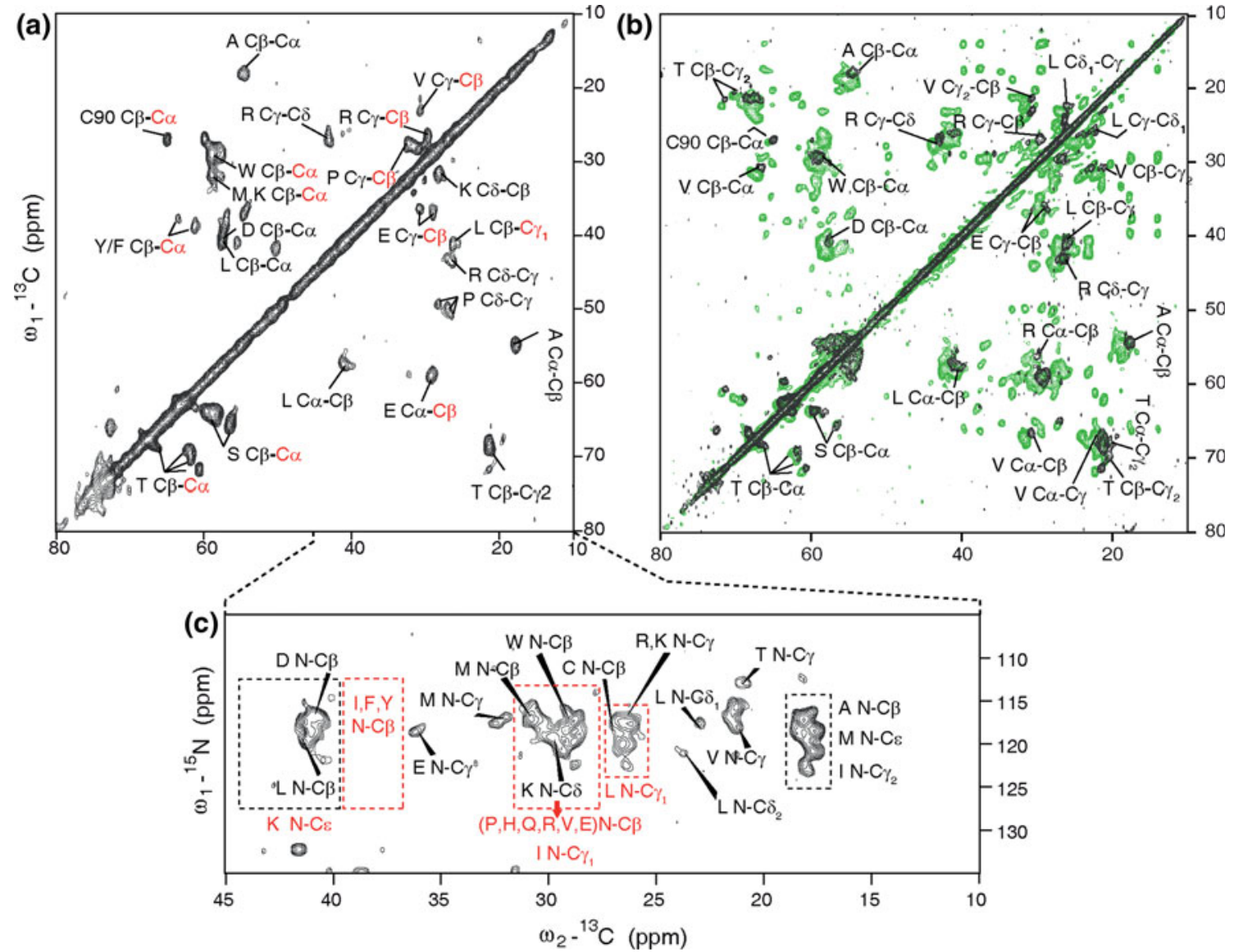

Fig. 1 a $\left({ }^{13} \mathrm{C},{ }^{13} \mathrm{C}\right)$ PDSD correlation spectrum recorded on $\left[{ }^{1} \mathrm{H} /{ }^{2} \mathrm{H},{ }^{13} \mathrm{C},{ }^{15} \mathrm{~N}\right] \mathrm{KcsA}-\mathrm{Kv} 1.3$ with a mixing time of $20 \mathrm{~ms}$. b Overlay of $\left({ }^{13} \mathrm{C},{ }^{13} \mathrm{C}\right)$ PDSD correlation spectra recorded on $\left[{ }^{1} \mathrm{H} /{ }^{2} \mathrm{H},{ }^{13} \mathrm{C},{ }^{15} \mathrm{~N}\right]$ (black, in Asolectin lipids) and $\left[{ }^{1} \mathrm{H}^{13}{ }^{13},{ }^{15} \mathrm{~N}\right]$ (green, in PC/PI lipids) KcsA-Kv1.3 at pH 7.4 acquired under similar experimental conditions (MAS: $10.92 \mathrm{kHz}, \mathrm{T}$ : $7^{\circ} \mathrm{C}, 700 \mathrm{MHz}$ ) but with a $\mathrm{CP}$ of $900 \mu \mathrm{s}$. c Cut-out of the aliphatic region of an NCACB-type correlation spectrum recorded with DARR mixing for $100 \mathrm{~ms}$ on $\left[{ }^{1} \mathrm{H} /{ }^{2} \mathrm{H},{ }^{13} \mathrm{C},{ }^{15} \mathrm{~N}\right]$ $\mathrm{Kcs} A-\mathrm{Kv} 1.3$. N-C cross peaks suppressed by fractional deuteration are indicated in red in several spectral regions. Amino acids are given in single letter notation 
solution-state NMR studies (Rosen et al. 1996; Shekhtman et al. 2002; Otten et al. 2010), C $\alpha$ positions of all amino acids are largely deuterated because the respective ketoacid undergoes a transamination reaction during synthesis (Nelson and Cox 2008). To further explore the residual ${ }^{1} \mathrm{H}$ pattern, we conducted a conventional NCACB correlation experiment (Baldus 2002) using $\left({ }^{13} \mathrm{C},{ }^{13} \mathrm{C}\right)$ DARR (Takegoshi et al. 2001) mixing (Fig. 1c). Similar to the results of the $\left({ }^{13} \mathrm{C},{ }^{13} \mathrm{C}\right)$ correlation experiments, the NCA part of the spectrum largely agrees with data obtained on a protonated version (Supporting Figure 1) of the channel but the aliphatic region of the spectrum lacks several of the correlations that involve deuterated $\mathrm{C} \beta$ or $\mathrm{C} \gamma$ positions. Indeed, $\mathrm{C} \beta$ positions of Glu, Gln, Pro and Arg that relate to $\alpha$-Ketoglutarate as precursor in the biosynthetic pathway (Ref. (Nelson and Cox 2008), see also supporting table 1) are largely removed compared to the protonated case (Fig. 1c, red and Fig. 1b, green). Additional missing intensities relate to $\mathrm{C} \beta$ positions of $\mathrm{Val}$ and Ile, the aromatic amino acids of Phe, Tyr and His as well as the $\mathrm{C} \gamma_{1}$ positions of Leu and Ile residues. On the other hand, pyruvate serves as a precursor to alkyl containing residues by direct incorporation (Ala, Val, Ile, Leu, Lys, etc.) or to aromatic amino acids and amino acids derived from Serine via other metabolites such as phosphoenol pyruvate and 3 phosphoglycerate (Supporting table 1). Hence, side chains of several amino acids containing alkyl groups are expected to exhibit sizable levels of protonation in line with our data. The protonation pattern at the remaining positions of amino acids is subject to residual protons from glucose itself and various intermediary steps that include cyclization, hydration, transamination or decarboxylation (Nelson and Cox 2008).

To directly infer the residual level of protonation, we conducted a $\left({ }^{1} \mathrm{H},{ }^{13} \mathrm{C}\right)$ HETCOR experiment using FSLG decoupling (Bielecki et al. 1989) in the $t_{1}$ dimension (Fig. 2). Compared to the case of the protonated channel (Lange et al. 2006b), the ${ }^{1} \mathrm{H}^{-13} \mathrm{C}$ dispersion is remarkably improved. Firstly, all $\mathrm{H} \alpha-\mathrm{C} \alpha$ correlations are largely eliminated and only some residual Ala, Leu, Glu $\mathrm{H} \alpha$ protonation remains. Because of the strong suppression of $\mathrm{H} \alpha$ protonation, the ${ }^{1} \mathrm{H}^{13}{ }^{13} \mathrm{C}$ polarization transfer dynamics are determined by the residual $\mathrm{NH}$ and side-chain protonation level (Fig. 2, insert). Note that a similar transfer profile would require significantly longer mixing time in the case of soluble molecules where transfer occurs via through bond interactions. For amino acids such as Lys, Ile, Phe or Tyr, we expect dominant ${ }^{1} \mathrm{H}^{-13} \mathrm{C}$ correlations within the $\mathrm{NH}$ resonance regime (dashed boxes in Fig. 2). On the other hand, $\mathrm{H} \beta-\mathrm{C} \beta$ correlations can be readily identified for $\mathrm{Thr}$, Cys, Ser residues in the spectrum (green box) in full accordance with our CC/NC data. Finally, a considerable reduction in spectral crowding is also visible in the methyl region of the $\left({ }^{1} \mathrm{H},{ }^{13} \mathrm{C}\right)$ spectrum. Here, the spectrum is a result of the superposition of different methyl isotopomers that contribute to the residual protonation pattern of Ala, Thr, Val, Ile and Leu (Rosen et al. 1996; Shekhtman et al. 2002; Otten et al. 2010). Indeed, additional ${ }^{13} \mathrm{C}$-edited double quantum-single quantum ${ }^{1} \mathrm{H}$ filtered experiments (Fig. 3) revealed a variety of correlations involving methyl proton pairs. Correlations between amide protons and aliphatic protons confirmed our FSLG HETCOR results. Furthermore, correlations involving Thr, Ser and Cys residues that appeared at $10 \mathrm{ppm}$ in the ${ }^{1} \mathrm{H}$ DQ dimension suggest that the $\mathrm{H} \beta$ positions of these residues are fully protonated. From our 2D data, we estimate ${ }^{1} \mathrm{H}$ line widths ranging between 0.26 (Ile $\mathrm{H} \delta$ ) and $0.4 \mathrm{ppm}(\mathrm{Thr} \mathrm{H} \beta$ ).

A more detailed analysis will be possible using topology schemes developed for solid-state NMR (Sakellariou et al. 2001) or using three-dimensional ${ }^{1} \mathrm{H}_{-}{ }^{1} \mathrm{H}^{-}{ }^{13} \mathrm{C}$ or ${ }^{1} \mathrm{H}_{-}{ }^{13} \mathrm{C}-{ }^{13} \mathrm{C}$

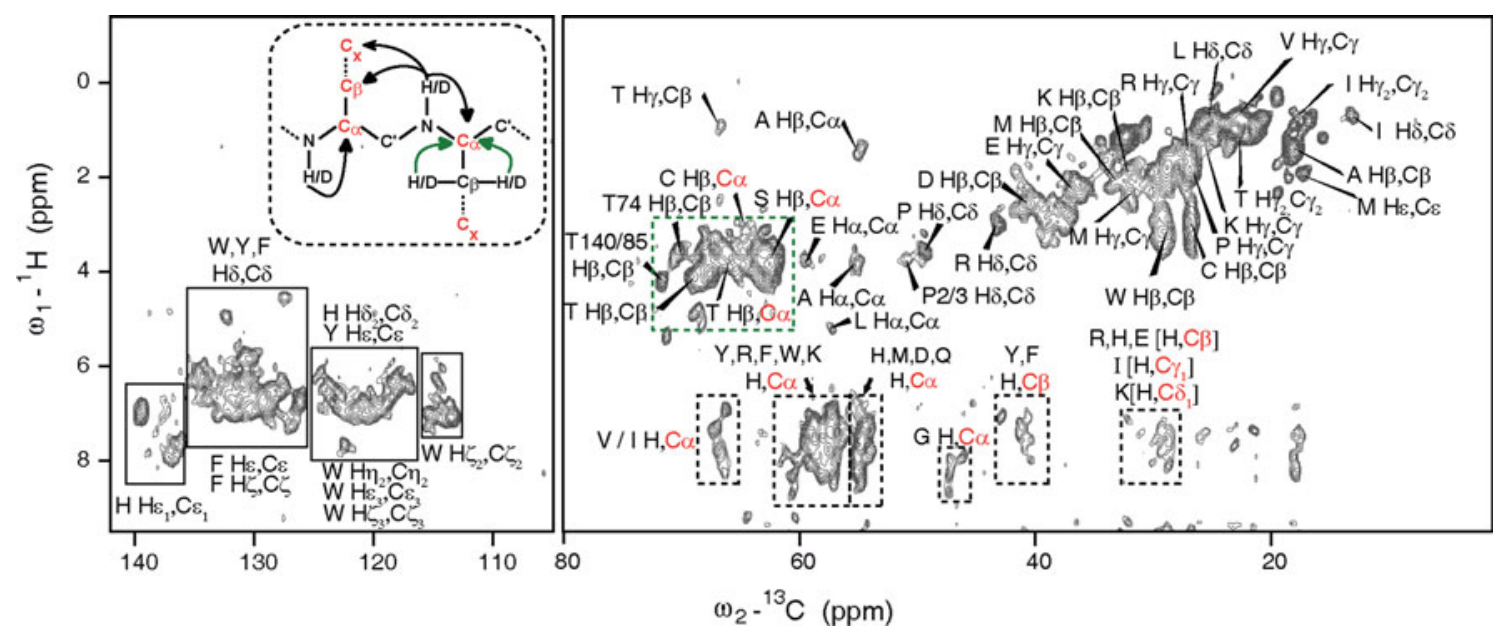

Fig. $2\left({ }^{1} \mathrm{H},{ }^{13} \mathrm{C}\right)$ FSLG-HETCOR spectra recorded on $\left[{ }^{1} \mathrm{H} /{ }^{2} \mathrm{H},{ }^{13} \mathrm{C},{ }^{15} \mathrm{~N}\right] \mathrm{KcsA}-\mathrm{Kv} 1.3$ (MAS: $13 \mathrm{kHz}, \mathrm{T}$ : $7^{\circ} \mathrm{C}$, CP contact time: $200 \mu \mathrm{s}$ ). A schematic representation of magnetization transfer is shown in the inset. Deuterated sites are given in red 

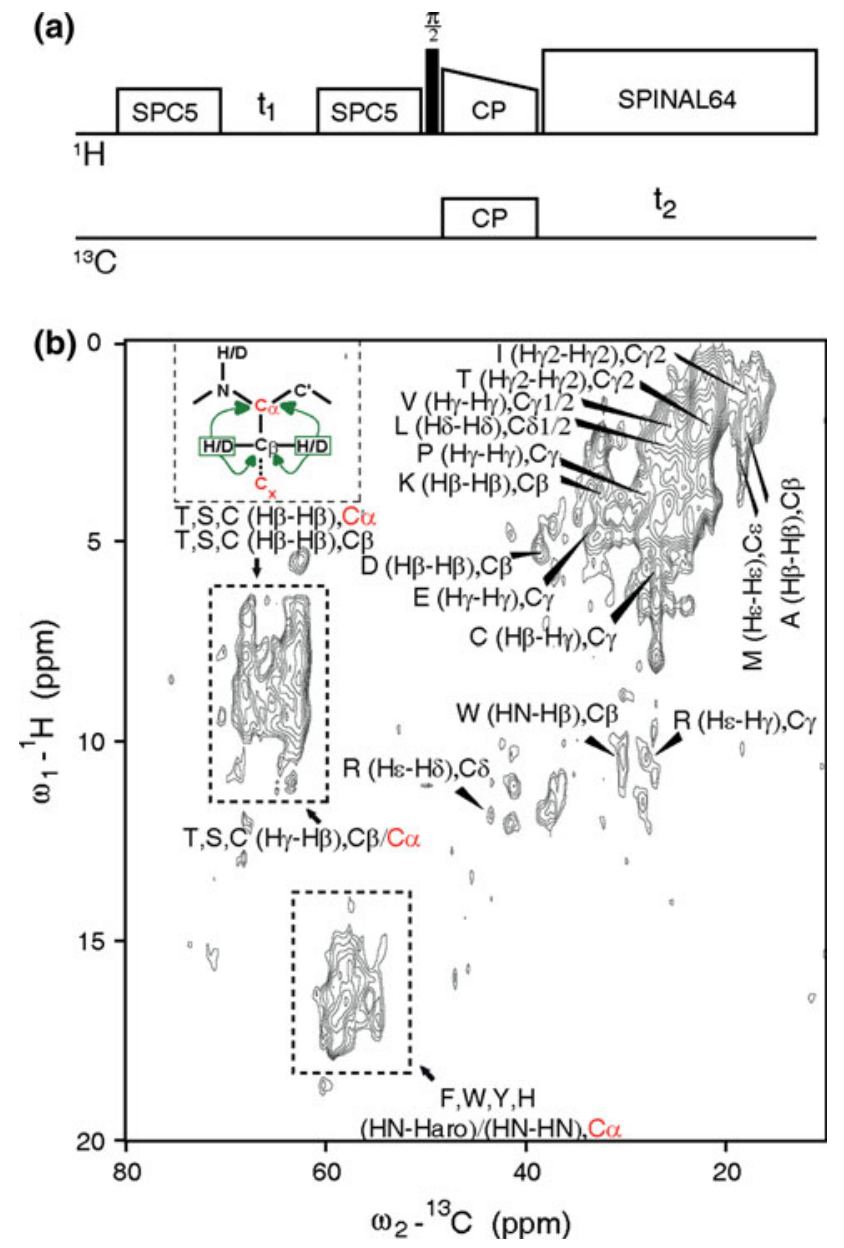

Fig. 3 a Pulse scheme for obtaining HH-C DQ-SQ correlations in two spectral dimensions. The SPC5 sequence is used for double quantum excitation and reconversion among dipolar coupled ${ }^{1} \mathrm{H}$ spins. After isotropic chemical shift evolution during $t_{1}$ and DQ reconversion, a short $\mathrm{CP}(90 \mu \mathrm{s})$ step ensures the transfer of magnetization of dipolar coupled protons to their directly attached carbon atoms which is read out during $\mathrm{t}_{2}$. b $\left({ }^{1} \mathrm{H}^{1} \mathrm{H}-{ }^{13} \mathrm{C}\right)$ DQ-SQ correlation spectrum recorded on $\left[{ }^{1} \mathrm{H} /{ }^{2} \mathrm{H},{ }^{13} \mathrm{C},{ }^{15} \mathrm{~N}\right]$ labeled $\mathrm{Kcs} A-$ $\mathrm{Kv} 1.3$ at $700 \mathrm{MHz}{ }^{1} \mathrm{H}$ resonance frequency with a ${ }^{1} \mathrm{H}-{ }^{1} \mathrm{H}$ DQ mixing time of $285 \mu$ s employing the SPC5 sequence (MAS: $14 \mathrm{kHz}, \mathrm{T}: 7^{\circ} \mathrm{C}$, CP contact time: $90 \mu \mathrm{s})$. A schematic representation of magnetization transfer of $\mathrm{H} \beta$ protons to surrounding carbons is shown in the inset. Deuterated sites are labeled in red

experiments. A summary of the residual protonation pattern at the carbon sites identified from our CC/NCACX and DQ-SQ $\left({ }^{1} \mathrm{H},{ }^{1} \mathrm{H}\right)-{ }^{13} \mathrm{C}$ experiments is given in supporting table 1 .

Assignments and structural constraints

Compared to the protonated case (Fig. 1b, green), fractional deuteration significantly reduces spectral complexity in complex biomolecules such the KcsA-Kv1.3 channel. We hence explored the use of such data for spectral

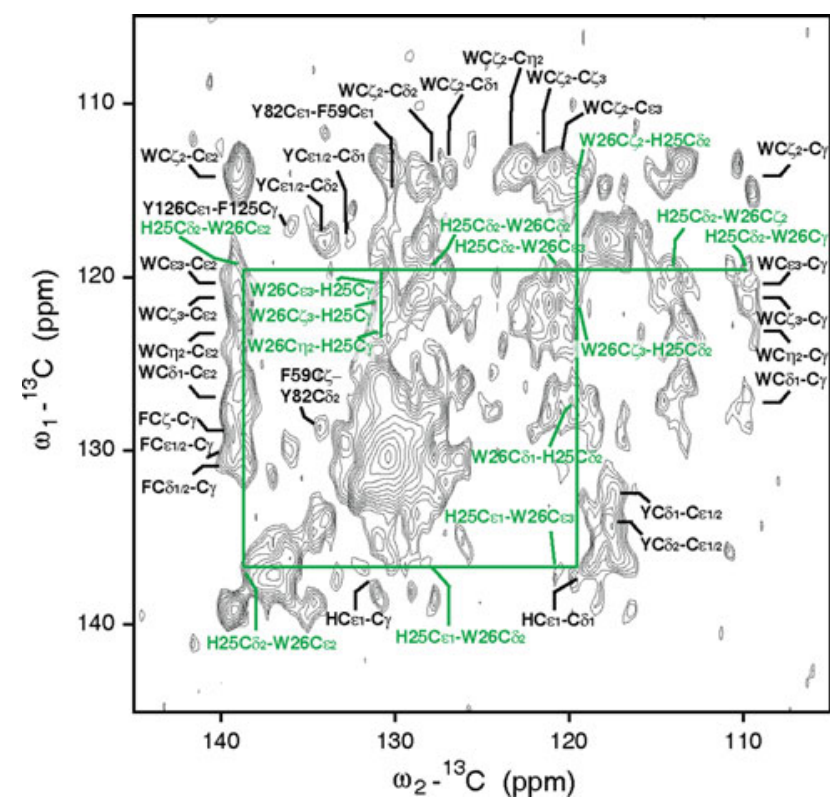

Fig. 4 Aromatic side-chain contacts identified in a $2 \mathrm{D}\left({ }^{13} \mathrm{C}-{ }^{13} \mathrm{C}\right)$ PDSD correlation spectrum recorded on $\left[{ }^{1} \mathrm{H} /{ }^{2} \mathrm{H},{ }^{13} \mathrm{C},{ }^{15} \mathrm{~N}\right] \mathrm{KcsA}-\mathrm{Kv} 1.3$ with a spin diffusion time of $200 \mathrm{~ms}$ and a CP time of $80 \mu \mathrm{s}$. A sequential walk for residues $\mathrm{H} 25$ and W26 is indicated by green lines. Unequivocally cross-peak assignments were made for correlations for which other spectral predictions are separated by at least $0.6 \mathrm{ppm}$ in one or two spectral dimensions

assignment as well as for the structural analysis. Firstly, knowledge of the protonation pattern and the unique amino acid sequence of KcsA-Kv1.3 readily allowed us to obtain resonance assignments for Cys90 (Fig. 1a) not reported previously (Ader et al. 2008; Ader et al. 2009a, b; Schneider et al. 2008).

Additional sequential as well as medium to long-range correlations became accessible by recording $\left({ }^{13} \mathrm{C},{ }^{13} \mathrm{C}\right)$ correlation experiments at mixing times beyond $100 \mathrm{~ms}$. Firstly, we directed our attention to correlations involving aromatic side-chains. Interestingly, we observed intense aromatic-aromatic side-chain correlations that were otherwise not visible in the fully protonated version of the channel (Supporting Figure 2). In Fig. 4, many of the observed correlations can be readily explained by intraresidue correlations within in the aromatic side-chains of Trp, Tyr and His. Apart from these, there are only 4 residue pairs that would give rise to sequential correlations, i.e., (H25, W26), (W67, W68), (W113, F114) and (H124, F125). Our analysis of these correlations with the structural model (see "Materials and methods") suggested that contacts in the range of $3.5-5 \AA$ are only expected for the aromatic side-chains of the $(\mathrm{H} 25, \mathrm{~W} 26)$ pair. The $\left({ }^{13} \mathrm{C},{ }^{13} \mathrm{C}\right)$ data at a $200 \mathrm{~ms}$ mixing and MAS rate of $10.92 \mathrm{kHz}$ were fully consistent with such sequential correlations (green lines in Fig. 4) leading to tentative aromatic side-chain assignments for $\mathrm{H} 25$ and W26. 
Fig. 5 a, b $2 \mathrm{D}\left({ }^{13} \mathrm{C},{ }^{13} \mathrm{C}\right)$ PDSD spectra of $\left[{ }^{1} \mathrm{H} /{ }^{2} \mathrm{H},{ }^{13} \mathrm{C},{ }^{15} \mathrm{~N}\right]$ KcsA-Kv1.3 recorded at $10.92 \mathrm{kHz}$ MAS and a CC mixing time of $500 \mathrm{~ms}$ employing a CP time of $80 \mu \mathrm{s}$. Potential intramolecular (black labels) and intermolecular (red labels) contacts identified have been indicated. c A selected set of contacts identified from ssNMR experiments (a, b) that are compatible with the structural model of KcsA-Kv1.3

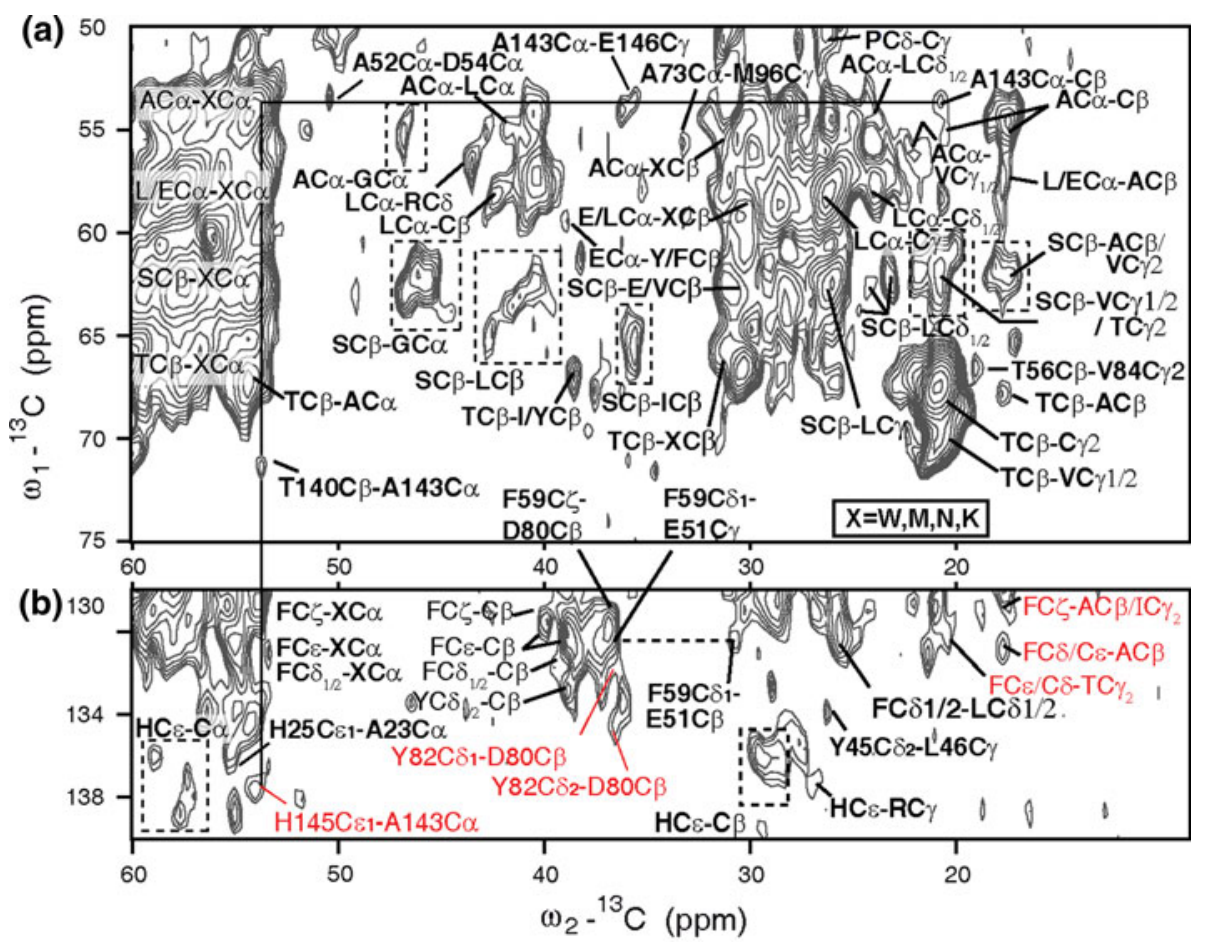

(c)

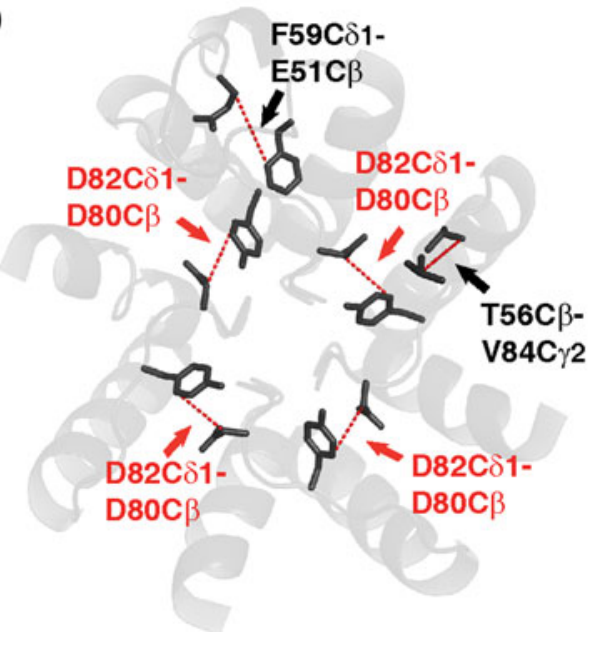

Subsequently, we investigated the use of $\left({ }^{13} \mathrm{C},{ }^{13} \mathrm{C}\right)$ PDSD data with longer mixing times. Compared to the protonated case, the resulting spectral congestion can be reduced by choosing short $\mathrm{CP}$ times of $80 \mu$ s that select for protonated ${ }^{13} \mathrm{C}$ sites as evolution and detection spins in $\mathrm{t}_{1}$ and $\mathrm{t}_{2}$. Spectral cut outs correlating aliphatic and aromatic-aliphatic regions for a ${ }^{13} \mathrm{C}_{-}{ }^{13} \mathrm{C}$ mixing time of $500 \mathrm{~ms}$ (MAS rate: $10.92 \mathrm{kHz}$ ) are shown in Fig. 5a and b, respectively. Even without residue-specific assignments, the observed correlations between $\mathrm{SC} \beta-\mathrm{AC} \beta, \mathrm{SC} \beta-\mathrm{LC} \beta$ and $\mathrm{SC} \beta-\mathrm{VC} \gamma 1 / 2$ spin pairs (indicated by dashed boxes in Fig. 5a) mostly encode medium to long-range correlations. Moreover, our structural model is compatible with the detection of a set of resolved long range and medium range intramolecular contacts. For example, starting with the chemical shift assignment on
T140C $\beta$ from our previous studies (Schneider et al. 2008) (Fig. 5a), we now identified a unique medium range correlation with the $\mathrm{A} 143 \mathrm{C} \alpha$ position. Other correlations relate to T56C $\beta$-V84C $\gamma_{2}$ or A52C $\alpha$-D54C $\alpha$ in Fig. 5a. The assignment of $\mathrm{A} 143 \mathrm{C} \alpha$ not only correlated to E146C $\gamma$ (Fig. 5a) but suggested polarization transfer to $\mathrm{H} 145 \mathrm{C} \varepsilon_{1}$ (Fig. 5b). Notably, the identified $\mathrm{H} 145 \mathrm{C} \varepsilon_{1}-\mathrm{A} 143 \mathrm{C} \alpha$ correlation can only be an intermolecular contact ( $4.3 \AA$ ) as the predicted intramolecular distance is significantly longer $(8.6 \AA)$. Additional contacts were also identified that connect L146C' and $\mathrm{F} 148 \mathrm{C} \delta_{2}$ to $\mathrm{H} 145 \mathrm{C} \varepsilon_{1}$. Finally, intermolecular contacts were also observed between residues $\mathrm{Y} 82 \mathrm{C} \delta_{1}$ and $\mathrm{D} 80 \mathrm{C} \beta$ (highlighted in red, Fig. 5c).

The transfer efficiency of proton-mediated longitudinal transfer schemes such as PDSD is dependent on the proton 


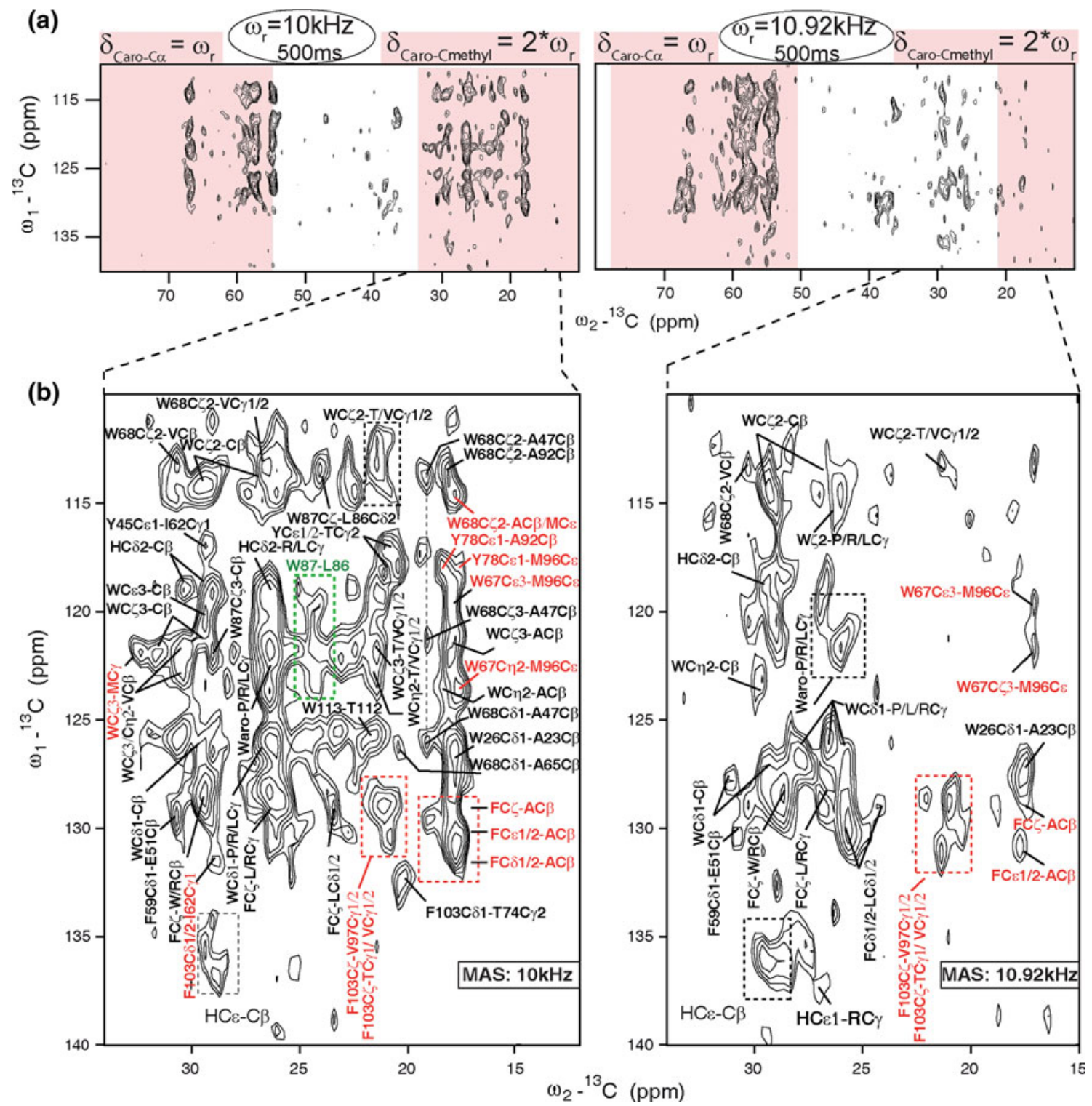

Fig. 6 a Cutouts from the $\left({ }^{13} \mathrm{C},{ }^{13} \mathrm{C}\right)$ PDSD spectra (using a mixing time of $500 \mathrm{~ms})$ employing two different MAS frequencies $(10 \mathrm{kHz}$ $\& 10.92 \mathrm{kHz}$ ) to enhance the rotational resonance recoupling between aromatic and methyl side-chain groups. The width of the red boxes is given by the size of chemical dispersion among aromatic ${ }^{13} \mathrm{C}$ frequencies. b Enlarged spectral regions with annotated intramolecular (black labels) and inter-molecular (red labels) contacts density and the MAS rate (see, e.g., Suter and Ernst 1985; Kubo and McDowell 1988; Oas et al. 1988; Colombo et al. 1988; Lange et al. 2003). The reduced proton density enhances the influence of rotational resonance (RR) effects that depend on the setting of the MAS rate relative to the chemical-shift difference among all spins exchanging polarization. We thus performed a series of $2 \mathrm{D}\left({ }^{13} \mathrm{C}-{ }^{13} \mathrm{C}\right)$ PDSD experiments with different MAS rates and $\left({ }^{13} \mathrm{C}-{ }^{13} \mathrm{C}\right)$ mixing times ranging between 20 and $500 \mathrm{~ms}$ to examine the MAS-dependence of the polarization transfer. For example, in Fig. 6 we compare the transfer profile between aromatic side-chains and methyls for two different MAS rates (left: $10 \mathrm{kHz}$, right: $10.92 \mathrm{kHz}$ ). In line with expectations based on the RR recoupling conditions for $\mathrm{C} \alpha-\mathrm{C}$, $\mathrm{C}_{\text {arom }}-\mathrm{C} \alpha / \mathrm{C}_{\text {methyl }} / \mathrm{C}^{\prime}$ pairs, polarization transfer becomes band-selective and is enhanced at $10 \mathrm{kHz}$ MAS.

Remaining intensities at $10.92 \mathrm{kHz}$ in the spectral regime $[40,25 \mathrm{ppm}]$ can be well explained by transfer across short, mostly intra-residue distances. The identified aromatic-aliphatic side-chain correlations are compatible with the detection of sequential side-chain contacts between L86 and W87 (green box) and long range contacts between W68 $\left(\mathrm{C} \zeta_{2}, \mathrm{C} \zeta_{3}, \mathrm{C} \eta_{2}\right)$ and $\mathrm{A} 47 \mathrm{C} \beta$. Furthermore, we could identify resolved intermonomer contacts between 


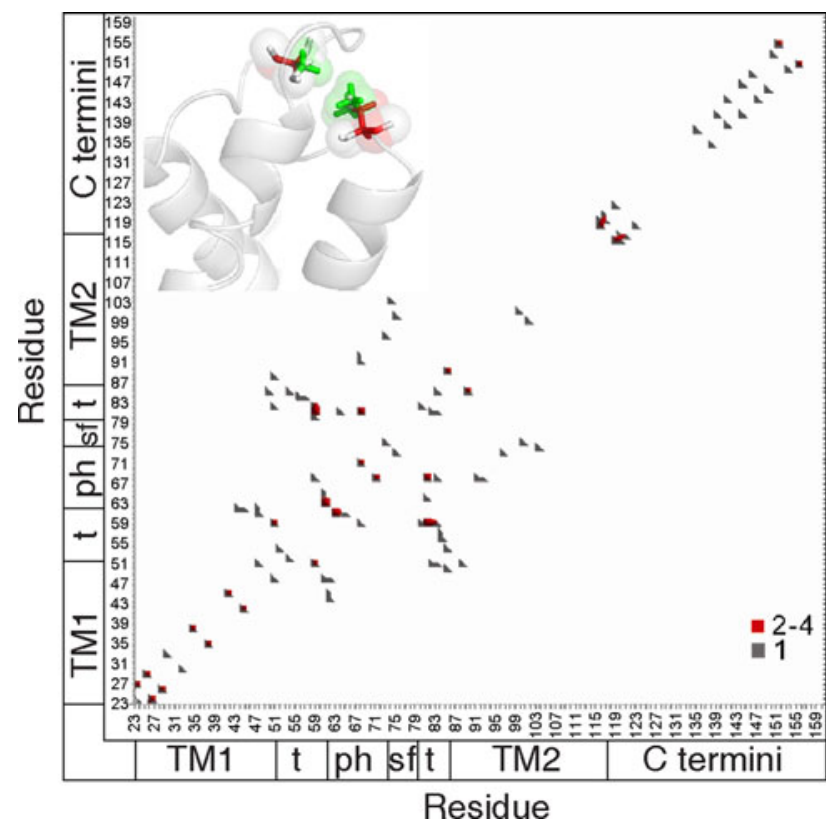

Fig. 7 Correlation plot containing resolved medium to long-range contacts and their occurrence identified in our ssNMR experiments on $\left[{ }^{1} \mathrm{H} /{ }^{2} \mathrm{H},{ }^{13} \mathrm{C},{ }^{15} \mathrm{~N}\right] \mathrm{KcsA}-\mathrm{Kv} 1.3$. A pictorial scheme describing polarization transfer mediated through protonated side-chains (green cloud) in the presence of a largely deuterated backbone (red) for the case of $\left[{ }^{1} \mathrm{H} /{ }^{2} \mathrm{H},{ }^{13} \mathrm{C},{ }^{15} \mathrm{~N}\right] \mathrm{KcsA}-\mathrm{Kv} 1.3$ is shown as an insert

the aromatic-aliphatic side-chains (highlighted in red) as well as cross peaks between specific amino acid pairs ( $\mathrm{F}-\mathrm{A}$ $\left.\mathrm{C} \beta, \mathrm{F}-\mathrm{T} / \mathrm{V} \mathrm{C} \gamma_{1 / 2}\right)$ that solely encode intermolecular contacts (red boxes).

Following the analysis of other spectral regions of our spectra, we could in total trace 62 assignments mostly involving side-chain atoms (see Supporting Information, Table 2). Furthermore, the data were, in conjunction with the structural model, compatible with the observation of 42 medium range, 36 long-range constraints (Supporting Information, Table 3) and 23 intermonomer contacts (Supporting Information, Table 4). In Fig. 7, these residue-residue contacts are displayed along the sequence and with the number of occurrences per residue.

\section{Conclusions}

Overall, our results on a fractionally deuterated ion channel embedded in lipid bilayers suggest a reduction in molecular protonation by approximately 50\% in line with earlier solution-state NMR work on globular proteins (Rosen et al. 1996; Shekhtman et al. 2002; Otten et al. 2010). Reminiscent of effects seen using specifically-labeled glycerol precursors during bacterial growth (LeMaster and Kushlan 1996; Hong 1999; Castellani et al. 2002), the exact deuteration level can vary in protein side-chains and methyl positions are expected to contain several isotopomers. In ${ }^{1} \mathrm{H}$ correlation experiments, we observed an improved spectral dispersion and a reduction in line width compared to the protonated case. In standard PDSD experiments on $\left[{ }^{1} \mathrm{H} /{ }^{2} \mathrm{H},{ }^{13} \mathrm{C},{ }^{15} \mathrm{~N}\right] \mathrm{Kcs} \mathrm{A}-\mathrm{Kv} 1.3$, one-bond $\left({ }^{13} \mathrm{C},{ }^{13} \mathrm{C}\right)$ correlations appeared after $20 \mathrm{~ms}$ mixing similar to fully protonated KcsA-Kv1.3 suggesting that polarization transfer dynamics are not strongly affected by the reduction in proton density. However, additional studies will be needed to dissect in detail the polarization transfer rates as a function of MAS rate, $B_{0}$ field and local proton density. In general, our experiments were conducted at modest MAS rates $(10-14 \mathrm{kHz})$, it seems likely that further improvements in ${ }^{1} \mathrm{H}$ line width and spectral resolution may be possible using a combination of dedicated pulse schemes (Sakellariou et al. 2000), ultra-fast MAS (Wickramasinghe et al. 2009; Bertini et al. 2010b) and ultra-high field NMR systems.

The reduced protonation level also simplifies the spectral analysis of ${ }^{13} \mathrm{C} /{ }^{15} \mathrm{~N}$ correlation experiments. Because residual protons are preferably found at the amino-acid side-chains (Fig. 7 insert, Supporting Information table 1), polarization transfer among and spectroscopic assignments of protein side-chain positions is facilitated. For long mixing times and longitudinal mixing schemes, protonmediated transfer becomes band-selective around the rotational resonance conditions among aliphatic, aromatic and carboxyl carbons. Experimental results shown here suggest that these conditions can aid the detection of medium to long-range correlations occurring in a particular spectral window. Notably, such measurements also revealed intermolecular contacts in our tetrameric $\left[{ }^{1} \mathrm{H} /{ }^{2} \mathrm{H},{ }^{13} \mathrm{C},{ }^{15} \mathrm{~N}\right]$ ion channel for which the combined application of dedicated ssNMR schemes and mixed labelling approaches that previously allowed detecting such constraints (see, e.g., Etzkorn et al. 2004; Wasmer et al. 2008; Etzkorn et al. 2010) is precluded. It seems likely that fractional deuteration will also facilitate the determination of longer internuclear distances using rotational-resonance recoupling (Spencer et al. 1991; Costa et al. 1997) or rotating-frame (Nomura et al. 1999; Sonnenberg et al. 2004) and MAS-modulated variants (Verel et al. 1997; Ramachandran et al. 2003) thereof. In addition, coherent transfer schemes that mediate $\left({ }^{13} \mathrm{C},{ }^{15} \mathrm{~N}\right)$ transfer via proton spins such as CHC (Seidel et al. 2005), PAR (Paepe et al. 2008) or PAIN-CP (De Paepe et al. 2011) experiments may be readily combined with fractional deuteration to suppress chemical-shift offset affects or to enhance transfer efficiencies.

Compared to schemes involving (partially) deuterated precursors, fractional deuteration reduces the influence of isotope effects on ssNMR chemical shifts (Hansen 1988) and offers a cost efficient way to sizably reduce protonation 
levels in complex biomolecules. These considerations and our results suggest that fractional deuteration can provide a powerful means to aid structural studies of complex biomolecules by high-resolution ssNMR.

Acknowledgments The research leading to these results has received funding from the European Community's Seventh Framework Programme (FP7/2007-2013) under grant agreement number 261863. Financial support from NWO is gratefully acknowledged (grants 700.26.121 and 700.58.102). We thank Karin Giller for technical support.

Open Access This article is distributed under the terms of the Creative Commons Attribution Noncommercial License which permits any noncommercial use, distribution, and reproduction in any medium, provided the original author(s) and source are credited.

\section{References}

Ader C, Schneider R, Hornig S, Velisetty P, Wilson EM, Lange A, Giller K, Ohmert I, Martin-Eauclaire M-F, Trauner D, Becker S, Pongs O, Baldus M (2008) A structural link between inactivation and block of a $\mathrm{K}^{+}$channel. Nat Struct Mol Biol 15:605-612

Ader C, Schneider R, Hornig S, Velisetty P, Vardanyan V, Giller K, Ohmert I, Becker S, Pongs O, Baldus M (2009a) Coupling of activation and inactivation gate in $\mathrm{K}^{+}$-channel: potassium and ligand sensitivity. EMBO J 28:2825-2834

Ader C, Schneider R, Seidel K, Etzkorn M, Becker S, Baldus M (2009b) Structural Rearrangements of membrane proteins probed by water-edited solid-state NMR spectroscopy. J Am Chem Soc 131:170-176

Ahuja S, Hornak V, Yan ECY, Syrett N, Goncalves JA, Hirshfeld A, Ziliox M, Sakmar TP, Sheves M, Reeves PJ, Smith SO, Eilers M (2009) Helix movement is coupled to displacement of the second extracellular loop in rhodopsin activation. Nat Struct Mol Biol 16:168-175

Andrew ER, Bradbury A, Eades RG (1958) Nuclear magnetic resonance spectra from a crystal rotated at high speed. Nature $182: 1659$

Andronesi OC, von Bergen M, Biernat J, Seidel K, Griesinger C, Mandelkow E, Baldus M (2008) Characterization of Alzheimer's-like paired helical filaments from the core domain of tau protein using solid-state NMR spectroscopy. J Am Chem Soc 130:5922-5928

Bajaj VS, Mak-Jurkauskas ML, Belenky M, Herzfeld J, Griffin RG (2009) Functional and shunt states of bacteriorhodopsin resolved by $250 \mathrm{GHz}$ dynamic nuclear polarization-enhanced solid-state NMR. Proc Natl Acad Sci USA 106:9244-9249

Baldus M (2002) Correlation experiments for assignment and structure elucidation of immobilized polypeptides under magic angle spinning. Prog Nucl Magn Reson Spectrosc 41:1-47

Baldus M, Petkova AT, Herzfeld J, Griffin RG (1998) Cross polarization in the tilted frame: assignment and spectral simplification in heteronuclear spin systems. Mol Phys 95:1197-1207

Bertini I, Bhaumik A, De Paepe G, Griffin RG, Lelli M, Lewandowski JR, Luchinat C (2010a) High-resolution solid-state $\mathrm{nmr}$ structure of a 17.6 kDa protein. J Am Chem Soc 132(3):10321040

Bertini I, Emsley L, Lelli M, Luchinat C, Mao J, Pintacuda G (2010b) Ultrafast MAS solid-state NMR permits extensive ${ }^{13} \mathrm{C}$ and ${ }^{1} \mathrm{H}$ detection in paramagnetic metalloproteins. J Am Chem Soc 132(16):5558-5559

Bielecki A, Kolbert AC, Levitt MH (1989) Frequency-switched pulse sequences: homonuclear decoupling and dilute spin NMR in solids. Chem Phys Lett 155:341-346

Bockmann A, Juy M, Bettler E, Emsley L, Galinier A, Penin F, Lesage A (2005) Water-protein hydrogen exchange in the microcrystalline protein $\mathrm{Crh}$ as observed by solid state NMR spectroscopy. J Biomol NMR 32:195-207

Cady SD, Schmidt-Rohr K, Wang J, Soto CS, DeGrado WF, Hong M (2010) Structure of the amantadine binding site of influenza M2 proton channels in lipid bilayers. Nature 463:689-692

Castellani F, van Rossum B, Diehl A, Schubert M, Rehbein K, Oschkinat H (2002) Structure of a protein determined by solid-state magicangle- spinning NMR spectroscopy. Nature 420:98-102

Chevelkov V, Rehbein K, Diehl A, Reif B (2006) Ultrahigh resolution in proton solid-state NMR spectroscopy at high levels of deuteration. Angew Chem Int Ed Engl 45:3878-3881

Colombo MG, Meier BH, Ernst RR (1988) Rotor-driven spin diffusion in natural-abundance ${ }^{13} \mathrm{C}$ spin systems. Chem Phys Lett 146:189-196

Costa PR, Kocisko DA, Sun BQ, Lansbury PT, Griffin RG (1997) Determination of peptide amide configuration in a model amyloid fibril by solid-state NMR. J Am Chem Soc 119:10487-10493

De Paepe G, Lewandowski JR, Loquet A, Eddy M, Megy S, Bockmann A, Griffin RG (2011) Heteronuclear proton assisted recoupling. J Chem Phys 134:95-101

Englander SW, Sosnick TR, Englander JJ, Mayne L (1996) Mechanisms and uses of hydrogen exchange. Curr Opinion Struct Biol 6:18-23

Etzkorn M, Böckmann A, Lange A, Baldus M (2004) Probing molecular interfaces using 2D magic-angle-spinning NMR on protein mixtures with different uniform labeling. J Am Chem Soc 126:14746-14751

Etzkorn M, Matell S, Andronesi OC, Seidel K, Engelhard M, Baldus M (2007) Secondary structure and topology of a seven-helix receptor in native membranes studied by solid-state NMR. Angew Chem-Int Edit 46:459-462

Etzkorn M, Seidel K, Li L, Martell S, Geyer M, Engelhard M, Baldus M (2010) Complex formation and light activation in membraneembedded sensory rhodopsin II as seen by solid-state NMR spectroscopy. Structure 18:293-300

Fung BM, Khitrin AK, Ermolaev K (2000) An improved broadband decoupling sequence for liquid crystals and solids. J Magn Reson 142:97-101

Gardner KH, Kay LE (1998) The use of ${ }^{2} \mathrm{H},{ }^{13} \mathrm{C},{ }^{15} \mathrm{~N}$ multidimensional NMR to study the structure and dynamics of proteins. Annu Rev Biophys Biomol Struct 27:357-406

Hansen PE (1988) Isotope effects in nuclear shielding. Prog Nucl Magn Reson Spectrosc 20:207-255

Heise H, Hoyer W, Becker S, Andronesi OC, Riedel D, Baldus M (2005) Molecular-level secondary structure, polymorphism, and dynamics of full-length $\alpha$-synuclein fibrils studied by solid-state NMR. Proc Natl Acad Sci USA 102:15871-15876

Hohwy M, Rienstra CM, Griffin RG (2002) Band-selective homonuclear dipolar recoupling in rotating solids. J Chem Phys 117:4973-4987

Hong M (1999) Resonance assignment of ${ }^{13} \mathrm{C} /{ }^{15} \mathrm{~N}$ labeled solid proteins by two- and three-dimensional magic-angle-spinning NMR. J Biomol NMR 15:1-14

Huber M, Hiller S, Schanda P, Ernst M, Bockmann A, Verel R, Meier BH (2011) A proton-detected 4D solid-state nmr experiment for protein structure determination. Chem Phys Chem 12:915-918

Jehle S, Rajagopal P, Bardiaux B, Markovic S, Kuhne R, Stout JR, Higman VA, Klevit RE, van Rossum BJ, Oschkinat H (2010) 
Solid-state NMR and SAXS studies provide a structural basis for the activation of $\alpha \mathrm{B}$-crystallin oligomers. Nat Struct Mol Biol 17:1037-1042

Kubo A, McDowell CA (1988) Spectral spin diffusion in polycrystalline solids under magic-angle spinning. J Chem Soc Faraday Trans 84:3713-3730

Kumar A, Heise H, Blommers MJJ, Krastel P, Schmitt E, Petersen F, Jeganathan S, Mandelkow EM, Carlomagno T, Griesinger C, Baldus M (2010) Interaction of epothilone B (Patupilone) with microtubules as detected by two-dimensional solid-state NMR spectroscopy. Angew Chem-Int Edit 49:7504-7507

Lange A, Luca S, Baldus M (2002) Structural constraints from proton-mediated rare-spin correlation spectroscopy in rotating solids. J Am Chem Soc 124:9704-9705

Lange A, Seidel K, Verdier L, Luca S, Baldus M (2003) Analysis of proton-proton transfer dynamics in rotating solids and their use for 3D structure determination. J Am Chem Soc 125:1264012648

Lange A, Becker S, Seidel K, Giller K, Pongs O, Baldus M (2005) A concept for rapid protein-structure determination by solid-state NMR spectroscopy. Angew Chem-Int Edit 44:2089-2092

Lange A, Giller K, Hornig S, Martin-Eauclaire M-F, Pongs O, Becker S, Baldus M (2006a) Toxin-induced conformational changes in a potassium channel revealed by solid-state NMR. Nature 440:959-962

Lange A, Giller K, Pongs O, Becker S, Baldus M (2006b) Twodimensional solid-state NMR applied to a chimeric potassium channel. J Recept Sig Transd 26:379-393

Legros C, Pollmann V, Knaus H-G, Farrell AM, Darbon H, Bougis PE, Martin-Eauclaire M-F, Pongs O (2000) Generating a high affinity scorpion toxin receptor in KcsA-Kv1.3 chimeric potassium channels. J Biol Chem 275:16918-16924

LeMaster DM, Kushlan DM (1996) Dynamical mapping of E-coli thioredoxin via ${ }^{13} \mathrm{C}$ NMR relaxation analysis. J Am Chem Soc 118:9255-9264

Lesage A, Emsley L, Penin F, Bockmann A (2006) Investigation of dipolar-mediated water-protein interactions in microcrystalline Crh by solid-state NMR spectroscopy. J Am Chem Soc 128:8246-8255

Linser R, Dasari M, Hiller M, Higman V, Fink U, Lopez del Amo JM, Markovic S, Handel L, Kessler B, Schmieder P, Oesterhelt D, Oschkinat H, Reif B (2011) Proton-detected solid-state NMR spectroscopy of fibrillar and membrane proteins. Angew Chem Int Ed Engl 50:4508-4512

Manolikas T, Herrmann T, Meier BH (2008) Protein structure determination from ${ }^{13} \mathrm{C}$ spin-diffusion solid-state NMR spectroscopy. J Am Chem Soc 130:3959-3966

McDermott AE, Creuzet FJ, Kolbert AC, Griffin RG (1992) Highresolution magic-angle-spinning NMR spectra of protons in deuterated solids. J Magn Reson 98:408-413

Nelson DL, Cox MM (2008) Lehninger principles of biochemistry, 5 th edn. Freeman, New York

Nomura K, Takegoshi K, Terao T, Uchida K, Kainosho M (1999) Determination of the complete structure of a uniformly labeled molecule by rotational resonance solid-state NMR in the tilted rotating frame. J Am Chem Soc 121:4064-4065

Oas TG, Griffin RG, Levitt MH (1988) Rotary resonance recoupling of dipolar interactions in solid- state nuclear magnetic-resonance spectroscopy. J Chem Phys 89:692-695

Otten R, Chu B, Krewulak KD, Vogel HJ, Mulder FAA (2010) Comprehensive and cost-effective NMR spectroscopy of methyl groups in large proteins. J Am Chem Soc 132:2952-2960

Paepe GD, Lewandowski JR, Loquet A, Bockmann A, Griffin RG (2008) Proton assisted recoupling and protein structure determination. J Chem Phys 129:245101
Paulson EK, Morcombe CR, Gaponenko V, Dancheck B, Byrd RA, Zilm KW (2003) Sensitive high resolution inverse detection NMR spectroscopy of proteins in the solid state. J Am Chem Soc 125:15831-15836

Pines A, Ruben DJ, Vega S, Mehring M (1976) New approach to high-resolution proton NMR in solids-deuterium spin decoupling by multiple-quantum transitions. Phys Rev Lett 36:110-113

Poyraz O, Schmidt H, Seidel K, Delissen F, Ader C, Tenenboim H, Goosmann C, Laube B, Thunemann AF, Zychlinsky A, Baldus M, Lange A, Griesinger C, Kolbe M (2010) Protein refolding is required for assembly of the type three secretion needle. Nat Struct Mol Biol 17:788-792

Ramachandran R, Ladizhansky V, Bajaj VS, Griffin RG $(2003){ }^{13} \mathrm{C}-{ }^{13} \mathrm{C}$ rotational resonance width distance measurements in uniformly ${ }^{13}$ C-labeled peptides. J Am Chem Soc 125:15623-15629

Reif B, Jaroniec CP, Rienstra CM, Hohwy M, Griffin RG (2001) ${ }^{1} \mathrm{H}-{ }^{1} \mathrm{H}$ MAS correlation spectroscopy and distance measurements in a deuterated peptide. J Magn Reson 151:320-327

Reif B, van Rossum BJ, Castellani F, Rehbein K, Diehl A, Oschkinat $\mathrm{H}$ (2003) Characterization of ${ }^{1} \mathrm{H}-{ }^{1} \mathrm{H}$ distances in a uniformly ${ }^{2} \mathrm{H}$, ${ }^{15} \mathrm{~N}$ labeled SH3 domain by MAS solid-state NMR spectroscopy. J Am Chem Soc 125:1488-1489

Renault M, Cukkemane A, Baldus M (2010) Solid-state NMR spectroscopy on complex biomolecules. Angew Chem-Int Edit 49:8346-8357

Rienstra CM, Tucker-Kellogg L, Jaroniec CP, Hohwy M, Reif B, McMahon MT, Tidor B, Lozano-Perez T, Griffin RG (2002) De novo determination of peptide structure with solid-state magicangle spinning NMR spectroscopy. Proc Natl Acad Sci USA 99:10260-10265

Rosen MK, Gardner KH, Willis RC, Parris WE, Pawson T, Kay LE (1996) Selective methyl group protonation of perdeuterated proteins. J Mol Biol 263:627-636

Sakellariou D, Lesage A, Hodgkinson P, Emsley L (2000) Homonuclear dipolar decoupling in solid-state NMR using continuous phase modulation. Chem Phys Lett 319:253-260

Sakellariou D, Lesage A, Emsley L (2001) Spectral editing in solidstate NMR using scalar multiple quantum filters. J Magn Reson 151:40-47

Schneider R, Ader C, Lange A, Giller K, Hornig S, Pongs O, Becker S, Baldus M (2008) Solid-state NMR spectroscopy applied to a chimeric potassium channel in lipid bilayers. J Am Chem Soc 130:7427-7435

Seidel K, Etzkorn M, Sonnenberg L, Griesinger C, Sebald A, Baldus M (2005) Studying 3D structure and dynamics by highresolution solid-state NMR: application to L-tyrosine-ethylester. J Phys Chem A 109:2436-2442

Shekhtman A, Ghose R, Goger M, Cowburn D (2002) NMR structure determination and investigation using a reduced proton (REDPRO) labeling strategy for proteins. FEBS Lett 524:177-182

Shi LC, Ahmed MAM, Zhang WR, Whited G, Brown LS, Ladizhansky V (2009) Three-dimensional solid-state NMR study of a seven-helical integral membrane proton pumpstructural insights. J Mol Biol 386:1078-1093

Sonnenberg L, Luca S, Baldus M (2004) Multiple-spin analysis of $\left({ }^{13} \mathrm{C},{ }^{13} \mathrm{C}\right)$ chemical-shift selective transfer in uniformly labeled biomolecules. J Magn Reson 166:100-110

Spencer RG, Halverson KJ, Auger M, McDermott AE, Griffin RG, Lansbury PT Jr (1991) An unusual peptide conformation may precipitate amyloid formation in Alzheimer's disease: application of solid-state NMR to the determination of protein secondary structure. Biochemistry 30:10382-10387

Sun S, Siglin A, Williams JC, Polenova T (2009) Solid-state and solution NMR studies of the CAP-Gly domain of mammalian 
dynactin and its interaction with microtubules. J Am Chem Soc 131:10113-10126

Suter D, Ernst RR (1985) Spin diffusion in resolved solid-state NMRspectra. Phys Rev B 32:5608-5627

Takegoshi K, Nakamura S, Terao T $(2001){ }^{13} \mathrm{C}-{ }^{1} \mathrm{H}$ dipolar-assisted rotational resonance in magic-angle spinning NMR. Chem Phys Lett 344:631-637

Uysal S, Vasquez V, Tereshko V, Esaki K, Fellouse FA, Sidhu SS, Koide S, Perozo E, Kossiakoff A (2009) Crystal structure of fulllength KcsA in its closed conformation. Proc Natl Acad Sci USA 106:6644-6649

Varga K, Ashmovska L, Parrot I, Dauvergne MT, Haertlein M, Forsyth V, Watts A (2007) NMR crystallography: the effect of deuteration on high resolution ${ }^{13} \mathrm{C}$ solid state NMR spectra of a 7-TM protein. Biochim Biophys Acta-Biomembr 1768:3029-3035

Verel R, Baldus M, Nijman M, van Os JWM, Meier BH (1997) Adiabatic homonuclear polarization transfer in magic-anglespinning solid-state NMR. Chem Phys Lett 280:31-39
Wasmer C, Lange A, Van Melckebeke H, Siemer AB, Riek R, Meier BH (2008) Amyloid fibrils of the HET-s(218-289) prion form a $\beta$ solenoid with a triangular hydrophobic core. Science 319:1523-1526

Wickramasinghe NP, Parthasarathy S, Jones CR, Bhardwaj C, Long F, Kotecha M, Mehboob S, Fung LWM, Past J, Samoson A, Ishii Y (2009) Nanomole-scale protein solid-state NMR by breaking intrinsic ${ }^{1} \mathrm{H}$ T1 boundaries. Nat Meth 6:215-218

Zheng L, Fishbein KW, Griffin RG, Herzfeld J (1993) Twodimensional solid-state ${ }^{1} \mathrm{H}$ NMR and proton exchange. J Am Chem Soc 115:6254-6261

Zhou DH, Shea JJ, Nieuwkoop AJ, Franks WT, Wylie BJ, Mullen C, Sandoz D, Rienstra CM (2007) Solid-state protein-structure determination with proton-detected triple-resonance $3 \mathrm{D}$ magicangle-spinning NMR spectroscopy. Angew Chem-Int Edit 46:8380-8383 